16. Бондарь В.А. Экологическая безопасность использования газового топлива / Бондарь В.А. АвтоГазоЗаправочныйКомплекс + Альтернативное Топливо (АГЗК + АТ). 2003. - №2(8) - С. 64-69

17. Балабаева И. Биодизельный бум в Германии // Балабаева И. Автомобильный транспорт. 2005. - №12. C. 40

18. Бензиновый вопрос [Електронний ресурс] // Автобизнес : маркетинговый автомобильный журнал [Сайт]. URL: http://www.abiz.ru/ru/2/20/428/?nid=956\&a=entry.show

19. Митрова Т. Тенденции и риски развития мировой энергетики [Електронний ресурс] // Перспективы [сайт] : сетевое издание Центра исследований и аналитики Фонда исторической перспективы. URL: http://www.perspektivy.info/rus/gos/tendencii_i_riski_razvitiya_mirovoiy_energ etiki.htm

20. Строганов В.И. Концепция обеспечения качества и надежности электромобилей и автомобилей с гибридной силовой установкой / В. И. Строганов, В. Н. Козловский // Электроника и электрооборудование транспорта. 2012. -№5-6.-С. 49-55.

21. Строганов В.И. Аналитическое моделирование тяговой системы электромобилен и автомобилей с комбинированной силовой установкой // В.И. Строганов, В.Н. Козловский, А.Г. Сорокин А.Г., Л.Н. Мифтахова // Вестник Казанского технологического университета. -2014. - №7. - С. 107-113

Рукопис подано до редакції 04.11.2019

УДК 614.8:331.45:331.421:331.582.2

К.В. ДАНОВА;, В.В. МАЛИШЕВА, кандидати техн. наук, доценти

Харківський національний університет міського господарства імені О.М. Бекетова

\title{
ІНФОРМАЦЙНА ЕНТРОПІЯ ЯК ПОКАЗНИК НЕВИЗНАЧЕНОСТІ У ЗАБЕЗПЕЧЕННІ БЕЗПЕКИ НА РОБОЧИХ МІСЦЯХ ПРАЦІВНИКІВ ІЗ ІНВАЛІДНІСТЮ
}

Мета. Аналіз можливості використання інформаційної ентропії як показника, що характеризує невизначеність у прийнятті управлінських рішень стосовно працевлаштування особи, яка має стійкі функціональні зміни у стані здоров'я, на робоче місце. За показником інформаційної ентропії особа, яка приймає управлінські рішення, має можливість визначати необхідність впровадження організаційно-технічних рішень щодо адаптації робочого місця із урахуванням обмежень життєдіяльності працівника із інвалідністю.

Методи дослідження. Методика грунтується на аналізі наявної статистичної інформації щодо причин травматизму, пов'язаного із виробництвом, на підприємствах переробної галузі, задля визначення вірогідності настання нещасного випадку за кожною групою як індивідуального ризику травмування. На базі цього визначено інформаційну ентропію. Врахування стану здоров'я осіб із інвалідністю пропонується здійснювати за інтегральним показником функціональної обмеженості життєдіяльності, який впливає на значення інформаційної ентропії, що надає можливість виробляти ефективні управлінські рішення щодо іiї зменшення та підвищення рівня охорони праці на робочих місцях працівників із інвалідністю та підприємстві у цілому.

Наукова новизна. Полягає у розробці підходу до прийняття управлінських рішень стосовно забезпечення охорони праці працівників із інвалідністю в умовах підприємства на основі врахування їх особливих потреб за інтегральним показником функціональної обмеженості життєдіяльності, що впливає на рівень інформаційної ентропії, яка відображає ефективність реалізації завдань щодо забезпечення безпеки на робочих місцях цієї категорії працівників.

Практичне значення. Полягає у наданні особі, яка приймає управлінські рішення, інформаційної бази для визначення пріоритетних напрямів підвищення рівня безпеки на робочих місцях відповідно до потреб працівника, який має стійкі функціональні зміни у стані здоров'я, з метою попередження зростання рівня виробничого травматизму. Зниження ризику травмування працівників із інвалідністю сприятиме посиленню позитивного ставлення до питання працевлаштування цієї категорії населення з боку роботодавців, що надасть змогу отримати суттєвий соціальноекономічний ефект на державному рівні.

Ключові слова: ентропія, невизначеність, ризик, працівник, інвалідність, травма, безпека.

doi: 10.31721/2306-5451-2019-1-49-20-25

Проблема та ії̈ зв'язок з науковими та практичними завданнями. Працевлаштування осіб із стійкими функціональними порушеннями у стані здоров'я на підприємства України $є$ важливим соціально-економічним завданням. Низький рівень трудової зайнятості осіб із інвалідністю призводить до негативних економічних наслідків, пов'язаних із втратою робочої сили, а також соціальних проблем, викликаних низьким рівнем доходу цієї категорії населення.

Квотний принцип працевлаштування осіб із обмеженими можливостями, що запроваджений Законом України «Про основи соціальної захищеності осіб з інвалідністю в Україні» [1], установлює норматив робочих місць для працевлаштування осіб з інвалідністю у розмірі чотирьох відсотків середньооблікової чисельності штатних працівників облікового складу за рік, а

(С) Данова К.В., Малишева В.В., 2019 
якщо працює від 8 до 25 осіб, - у кількості одного робочого місця для підприємств, установ, організацій, у тому числі підприємств, організацій, громадських організацій осіб з інвалідністю, фізичних осіб, які використовують найману працю тощо. Незважаючи на ці вимоги, рівень офіційного працевлаштування осіб із інвалідністю в Україні залишається вкрай низьким (близько $0,5 \%$ від загальної чисельності осіб із інвалідністю) [2].

Основною причиною низького рівня включення осіб із інвалідністю у виробничий процес $€$ складність у забезпеченні безпеки на робочому місці працівника із особливими потребами та високий рівень ризику, пов'язаного із виконанням трудових обов'язків цієї категорії працівників.

Аналіз досліджень і публікацій. Закон України «Про охорону праці» зобов'язує роботодавця впроваджувати заходи щодо організації безпечних та нешкідливих умов праці на робочих місцях працівників [3]. Враховуючи високий рівень ризику, пов'язаний із виконанням працівником, який має стійкі функціональні зміни у стані здоров'я, професійних обов'язків, роботодавець прагне уникнути додаткової небезпеки та створює певні перешкоди працевлаштуванню працівника із інвалідністю або пропонує «умовну» зайнятість, за якої працівник фактично не $\epsilon$ включеним у трудових процес. 3 огляду на сучасні європейські підходи до працевлаштування осіб із інвалідністю така форма зайнятості припускається лише у тих випадках, коли стан здоров'я працівника $\epsilon$ особливо складним і він майже не здатний до самообслуговування. У всіх інших випадках роботодавець має шукати шляхи залучення осіб із інвалідністю на робочі місця, забезпечуючи при цьому належний рівень безпеки.

В Україні вже тривалий час зберігається високий рівень виробничого травматизму, що пов'язано із недостатньою ефективністю системи керування охороною праці, значним фізичним та моральним зносом основних фондів виробництва та низьким рівнем уваги з боку роботодавця до питань охорони праці. На рис. 1 наведено статистичні дані по підприємствах переробної галузі, що відображають кількість потерпілих від нещасних випадків, пов'язаних із виробництвом, за групами причин згідно актів розслідування [2]. 3 наведених даних видно, що більшість працівників травмується з причин організаційного характеру (77-79\% від загальної чисельності потерпілих).

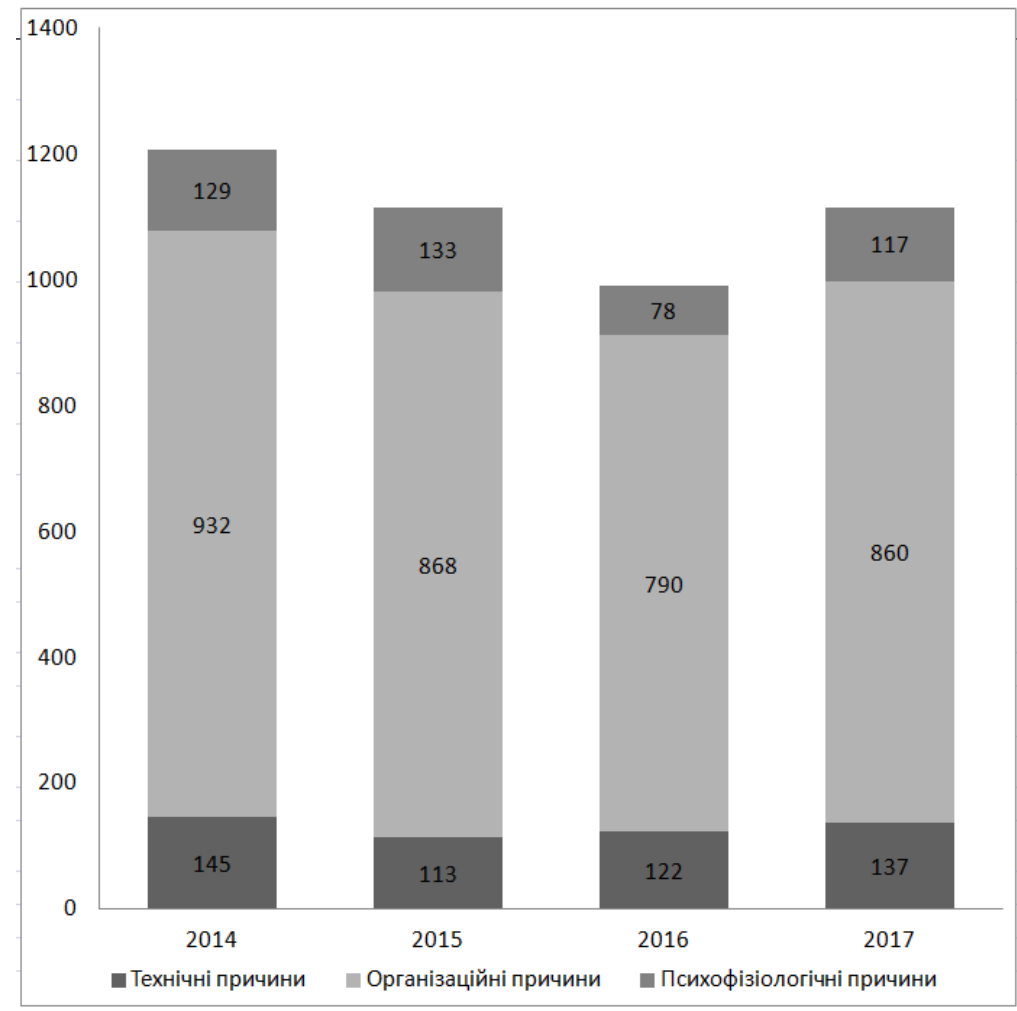

Рис. 1. Кількість потерпілих від травматизму, пов'язаного із виробництвом, на підприємствах переробної галузі України

Тобто недоліки у організації праці, а також неврахування технічних й психофізіологічних факторів у організації трудового процесу, обумовлюють настання нещасних випадків, що $є$ 
пов'язаними із виробництвом, для працівників, які не мають виражених стійких функціональних порушень у стані здоров'я.

Забезпечення безпеки осіб із інвалідністю на робочих місцях пов’язане, у першу чергу, із вирішенням питань щодо організації робочого місця та технологічного процесу із врахуванням психофізіологічних особливостей, обумовлених станом здоров'я працівника із особливими потребами. Підвищення рівня інформативності процесу прийняття управлінських рішень щодо вибору робочого місця, виробничого навантаження та врахування особливих потреб осіб із інвалідністю дозволить знизити ризики та підвищити рівень безпеки трудових процесів.

Закордонні вчені вже тривалий час досліджують питання щодо включення осіб із обмеженими можливостями у виробничий процес. Однак при цьому необхідно враховувати, що професійна діяльність цієї категорії працівників має бути організована із урахуванням особливих вимог безпеки, обумовлених їх фізичними чи нервово-психічними обмеженнями, наявність яких підвищує ймовірність настання нещасного випадку чи аварії.

При прийомі на роботу роботодавець зацікавлений у отриманні інформації про функціональні можливості працівника із інвалідністю та його рівень професійної працездатності, оскільки він має бути впевнений у тому, що працівник здатний безпечно та ефективно виконувати виробничі завдання, що йому доручатимуться [4]. Визначено, що у процесі найму на роботу працівника із особливими потребами перед роботодавцем постає низка питань, вирішення яких потребує певного інформаційного забезпечення: оцінка рівня кваліфікації та працездатності; сума витрат, необхідних на переоснащення робочого місця під потреби працівника із інвалідністю; особливості інтеграції працівника із інвалідністю та вплив на колектив; питання забезпечення безпеки на робочому місці.

Брак інформації з цих питань не дозволяє роботодавцеві організувати ефективну професійну інклюзію й безпеку та підвищує вразливість працівника із інвалідністю внаслідок впливу факторів виробничого середовища та трудового процесу [5].

Тому керівнику, який приймає рішення щодо працевлаштування особи із особливими потребами, підбору та адаптації робочого місця, важливо отримувати максимально повну інформацію у контексті трудової зайнятості, оскільки їі нестача призводить до зростання ступеня невизначеності процесу прийняття управлінських рішень.

Відповідно до [6], невизначеність означає сумнів, наприклад у достовірності результатів вимірювань, що обумовлюється відсутністю точного знання щодо значення величини, що вимірюється. При використанні даного терміну у контексті теорії інформації, невизначеність характеризує ситуацію браку інформації стосовно об'єкту управлінської функції. За допомогою даного терміну стандарт [7] надає визначення одному з ключових понять у сфері безпеки - терміну «ризик», який визначено як вплив невизначеності на мету. Таким чином, поняття невизначеності тісно пов'язане із питанням безпеки як у аспекті оцінки умов праці при проведенні метрологічних вимірювань, так і у ситуації прийняття управлінських рішень в умовах недостатньої інформації щодо досліджуваного об'єкта.

Постановка задачі. Завданням наукової статті $є$ дослідження рівня інформаційного забезпечення процесу прийняття управлінських рішень щодо зниження ризику травматизму на робочих місцях працівників із інвалідністю.

Викладення матеріалу та результати. Травматизм на робочих місцях, відповідно до Порядку розслідування нещасних випадків [8], визначається наступними групами причин:

технічні причини, що обумовлені конструкцією та експлуатаційним станом виробничого обладнання та технологічного процесу;

організаційні причини, що характеризуються особливостями функціонування системи управління охороною праці;

психофізіологічні причини, викликані впливом фізіологічних та психологічних особливостей працівника.

Група технічних причин виробничого травматизму, що, в основному, характеризується станом виробничого обладнання, засобів виробництва, транспорту та середовища, може бути записана у вигляді

$$
X_{1}=\left\{x_{11}, x_{12} x_{13}\right\}
$$


де $x_{11}$ - конструктивні недоліки, недосконалість засобів виробництва, що можуть призвести до травмування працівника, транспортних засобів; $x_{12}$ - невідповідності технологічного процесу, що становить небезпеку для працівника; $x_{13}$ - незадовільний технічний стан виробничих об’єктів, інженерних комунікацій, території, засобів виробництва, транспортних засобів, виробничого середовища.

Група організаційних причин включає в себе недоліки функціонування системи управління охороною праці, порушення вимог безпеки, трудової та виробничої дисципліни

$$
X_{2}=\left\{x_{21}, x_{22}, x_{23}, x_{24}\right\},
$$

де $x_{21}$ - недоліки функціонування системи управління охороною праці, невикористання засобів колективного чи індивідуального захисту; $x_{22}$ - недоліки під час проведення медичного обстеження (професійного відбору) працівника; $x_{23}$ - недоліки навчання 3 питань безпеки, складання інструкцій з охорони праці; $x_{24}$ - порушення вимог безпеки, трудової та виробничої дисципліни.

Психофізіологічні причини виробничого травматизму, пов'язані із впливом людського фактора, характеризуються як

$$
X_{3}=\left\{x_{31}, x_{32}, x_{33}\right\}
$$

де $x_{31}$ - незадовільні фізичні чи нервово-психічні характеристики працівника; $x_{32}$ - алкогольне, наркотичне отруєння (сп'яніння), особиста необережність; $x_{33}$ - незадовільний мікроклімат у колективі, протиправні дії осіб.

У разі розглядання випадків травматизму за окремими групами причин як дискретних подій, що $\epsilon$ несумісними, ймовірність настання травми за певною причиною може бути записана у вигляді

$$
P\left(\sum_{i=1}^{n} X_{i}\right)=\sum_{i=1}^{n} p\left(X_{i}\right)=\frac{\sum_{i=1}^{n} \sum_{j=1}^{m} x_{i j}}{N},
$$

де $X_{i}-i$-група причин травматизму, пов'язаного із виробництвом; $x_{i j}-j$-й нещасний випадок за $i$-ю групою; $N$ - середньоспискова чисельність працівників за галуззю, що розглядається.

Враховуючи це та використовуючи наявні статистичні дані (рис. 1), визначимо відносну ймовірність настання нещасного випадку за кожною групою як індивідуальний ризик травмування, отримуємо: $p_{1}=0,95 \cdot 10^{-4} ; p_{2}=6,37 \cdot 10^{-4} ; p_{3}=0,84 \cdot 10^{-4}$.

Ймовірність отримати травму зростає із збільшенням ступеня інформаційної невизначеності щодо небезпек, пов'язаних із технологічним обладнанням й процесами, функціонуванням системи управління охороною праці, а також психофізіологічним станом працівника.

Інформаційна невизначеність може бути виражена через ентропію за формулою К. Шеннона, за кожною групою причин

$$
H(X)=-\sum_{i=1}^{n} p\left(X_{i}\right) \log _{a} p\left(X_{i}\right),
$$

де $p_{i}$ - ймовірність настання небажаного наслідку у вигляді травмування працівника внаслідок браку інформації для прийняття управлінського рішення щодо попередження виробничого травматизму за $i$-ю групою причин; $a$ - основа логарифму, що обирається залежно від кількості можливих станів (у даному випадку розглядаються два стани: отримання чи неотримання травми працівником на робочому місці).

Враховуючи це, інформаційна невизначеність, що виражена через ентропію, щодо груп причин, що призвели до нещасних випадків, відповідно становитиме: $H\left(x_{1}\right)=0,00127$; $H\left(x_{2}\right)=0,00676 ; H\left(x_{3}\right)=0,00114$.

У випадку працевлаштування працівника із інвалідністю на певне робоче місце спостерігатиметься зростання невизначеності, що обумовлюється браком інформації щодо відповідності робочого місця, технологічного процесу, факторів оточуючого середовища та ін. особливим вимогам цієї категорії працівників, які можуть бути згруповані наступним чином:

ступінь відповідності виробничого обладнання та трудового процесу психофізіологічним особливостям працівника із інвалідністю (у контексті невідповідності параметрів виробничого обладнання та трудового процесу); 
здатність системи управління охороною праці забезпечити достатність організаційних заходів по забезпеченню безпеки на робочому місці працівника із інвалідністю; боти.

відповідність психофізіологічного стану працівника із інвалідністю змісту виконуваної ро-

Інвалідність працівника, що встановлюється за висновками медико-соціальної експертизи, характеризується поєднанням категорій обмеження життєдіяльності $u_{p}$, та ступеня вираженості критерію обмеження життєдіяльності $k_{j}$ [9]

$$
E_{p j}=\left\{u_{p}, k_{j}\right\}
$$

де $u_{p}$ - критерій обмеження життєдіяльності, що характеризує здатність людини до самообслуговування, пересування, орієнтації, контролю своєї поведінки, спілкування, навчання, виконання трудової діяльності згідно[10]; $k_{j}$ - ступінь вираженості критерію обмеження життєдіяльності (I - помірно виражений, II - виражений, III - значно виражений згідно[10]).

3 метою урахування обмежень життєдіяльності працівника із інвалідністю використовує інтегральний показник функціональної обмеженості життєдіяльності $I_{e}$, що характеризує загальний рівень обмеження життєдіяльності [9]

$$
I_{e}=\int_{u_{1}}^{u_{7}} f(u) d u .
$$

Аналіз складових основних причин виробничого травматизму за ф-ми (1-3) показав, що вплив функціональної обмеженості життєдіяльності на зростання рівня травматизму може очікуватися за усіма групами причин виробничого травматизму. Враховуючи це, запишемо ймовірність настання нещасного випадку за ф-ю (5) у вигляді

$$
P(X)=\frac{\sum_{i=1}^{n} \sum_{j=1}^{m} x_{i j}}{N_{1}+\sum_{k=1}^{p} I_{e_{k}} N_{2_{k}}},
$$

де $N_{1}$ - чисельність працівників без стійких функціональних змін у стані здоров'я; $N_{2 k}-$ чисельність працівників із інвалідністю $k$-ї групи за інтегральним показником функціональної обмеженості життєдіяльності $I_{e}$.

Враховуючи те, що, згідно статистичних даних, в Україні понад 14 \% населення працездатного віку мають інвалідність, та використовуючи вираз (8), визначимо ймовірність настання нещасного випадку у випадку, за якого із загальної чисельності працівників галузі 10 \% мають інвалідність III групи. Приймаємо інтегральний показник функціональної обмеженості життєдіяльності $I_{e}=0,8$. За таких умов ймовірність настання нещасного випадку із отриманням травми становитиме: $p_{1}=1,03 \cdot 10^{-4} ; p_{2}=6,92 \cdot 10^{-4} ; p_{3}=0,94 \cdot 10^{-4}$. В реальних умовах на підприємствах можуть бути працевлаштовані працівники не лише III, але й II групи інвалідності, що збільшує ймовірність травматизму.

Інформаційна невизначеність настання нещасного випадку, виражена через ентропію, відповідно становитиме: $H\left(x_{1}\right)=0,00136 ; H\left(x_{2}\right)=0,00726 ; H\left(x_{3}\right)=0,00126$.

Таким чином, врахування функціональних обмежень життєдіяльності працівників призвело до зростання рівня невизначеності стосовно організації безпеки праці на робочих місцях працівників із інвалідністю. При проведенні аналізу робочих місць показник ентропії дозволяє у зручній для особи, яка приймає рішення, формі отримати інформацію для вирішення питання щодо пріоритетності аналізу стану безпеки та впровадження відповідних заходів 3 охорони праці.

Висновки та напрямок подальших досліджень. Внаслідок наявності хронічного захворювання, вроджених вад, нещасного випадку людина може отримати стійкі функціональні зміни у стані здоров’я. При прийнятті на роботу особи із інвалідністю перед роботодавцем постає питання забезпечення належного рівня безпеки працівника та мінімізації ризиків, пов'язаних із виконанням працівником професійних завдань. Це може розглядатися як приклад прийняття рішення в умовах невизначеності, що істотно впливає на рівень безпеки на окремому робочому місці, у структурному підрозділі і, навіть, на рівні підприємства. 
3 метою визначення пріоритетності завдань щодо попередження виробничого травматизму на робочих місцях працівників із інвалідністю у статті запропоновано використовувати інформаційну ентропію як показник, що характеризує невизначеність стану безпеки на робочому місці. За значенням ентропії роботодавець може приймати обгрунтовані рішення щодо пріоритетності напрямів вдосконалення охорони праці на підприємстві.

\section{Список літератури}

1. Закон України «Про основи соціальної захищеності осіб з інвалідністю в Україні» : станом на 20 січ. 2018 р. / Верховна Рада України, http://zakon2.rada.gov.ua/laws/show/875-12.

2. Офіційний сайт Державної служби статистики України, http://www.ukrstat.gov.ua/.

3. Закон України «Про охорону праці» : станом на 20 січ. 2018 p., http://zakon2.rada.gov.ua/laws/show/875-12.

4. Bonaccio S. (2019) The Participation of People with Disabilities in the Workplace Across the Employment Cycle: Employer Concerns and Research Evidence / S. Bonaccio, C. E. Connelly, I. R. Gellatly // Journal of Business and Psychology. - 2019. - Volume 34. - pp. 1-24.

5. Breslin F. C. Examining occupational health and safety vulnerability among Canadian workers with disabilities / F. C. Breslin, A. M. Lay, A. Jetha, P. Smith // Disability and Rehabilitation Journal. - 2018. - Volume 40, issue 18. - pp. 2138-2143.

6. Uncertainty of measurement ISO/IEC GUIDE 98-3:2008(E), https://www.sis.se/api/document/preview/910301/.

7. Risk management - Guidelines ISO 31000:2018, https://pecb.com/whitepaper/iso-310002018-risk-managementguidelines.

8. Деякі питання розслідування та обліку нещасних випадків, професійних захворювань і аварій на виробництві, https://zakon.rada.gov.ua/laws/show/1232-2011-\%D0\%BF

9. Данова К.В. Функціональні обмеження осіб із інвалідністю в аспекті оцінки рівня працездатності та безпеки праці / К.В. Данова // Комунальне господарство міст. - Вип. 146. - С. 133-137.

10. Питання медико-соціальної експертизи, https://zakon.rada.gov.ua/laws/show/1317-2009-\%D0\%BF/page.

Рукопис подано до редакції 13.12.2019

УДК 622.271.33:622.12

С.О.ЛУЦЕНКО, канд. техн. наук, доц., В.Г.БЛІЗНЮКОВ, д-р техн. наук, проф., І.В.БАРАНОВ, канд. техн. наук

Криворізький національний університет

\section{ВИЗНАЧЕННЯ ПЕРСПЕКТИВНИХ КОНТУРІВ КАР'СРІВ, ЩО РОЗРОБЛЯЮТЬ КРУТОСПАДНІ ЗАЛІЗОРУДНІ РОДОВИЩА}

Мета. Удосконалити науково-методичну базу в області проектування і планування відкритих гірничих робіт шляхом розробки нових і коригування існуючих методів визначення границь відкритих гірничих робіт, на основі порівняння показників режимів гірничих робіт, що змінюються в часі, проектованого кар'єру і діючих (базових) кар'єрів.

Методи дослідження. Економічною основою розрахункового принципу визначення перспективної глибини проектованого кар'єру прийнято умову: в будь-який період розробки економічні показники виробництва і реалізації залізорудної продукції проектованого підприємства повинні бути краще або рівні аналогічних показників діючого (базового для порівняння) підприємства. Реалізація цієї умови досягнута із застосуванням геометричного аналізу кар'єрних полів і порівняння режимів гірничих робіт проектованого і діючого кар'єрів.

Наукова новизна. Розроблена методика відрізняється від відомих урахуванням зміни граничних коефіцієнтів розкриву в часі, а також визначенням впливу технологічних показників кар'єрів-конкурентів на кінцеву глибину кар'єру, що проектується [2].

Практична значимість. Результати виконаних досліджень можуть бути використані проектними організаціями і гірничодобувними підприємствами при визначенні перспективних контурів кар'єрів.

Результати. Приведено загальноприйнятий принцип визначення меж відкритих гірничих робіт, суть якого полягає у визначенні границь на основі порівняння допустимої собівартості видобутку руди з очікуваною за проектованим кар'єром [1]. Розроблена методика визначення границь кар'єрів, яка передбачає застосування граничного коефіцієнта розкриву як величини не постійної, а такої, що змінюється в часі, і залежить від зміни поточних коефіцієнтів розкриву на кар'єрах-конкурентах [2]. На прикладі кар'єрів, які відображають характерні особливості розробки крутоспадних родовищ України, продемонстровано вплив поточних коефіцієнтів розкриву діючих кар'єрів на граничний коефіцієнт розкриву, який служить головним критерієм при визначенні меж відкритих гірничих робіт для проектованих кар'єрів [2].

Ключові слова: відкриті гірничі роботи, перспективні контури кар'єра, кордони кар'єра, граничний коефіцієнт розкриву, глибина відкритих гірничих робіт, собівартість концентрату.

(c) Луценко С.О., Блізнюков В.Г., Баранов І.В., 2019 